\title{
Governance Symposium
}

\section{Municipal Government Structure in Wisconsin: Does Form Matter?}

Karl Nollenberger - University of Wisconsin - Oshkosh

James Simmons - University of Wisconsin - Oshkosh

\begin{abstract}
This article examines the forms of municipal governments in Wisconsin and their relationship to variables in the areas of socioeconomic, partisanship, election process, decision-making in the governance process, and internal municipal operations. Wisconsin has more mayor-council and mayoral forms with an appointed administrator rather than council-manager forms common in other states. We find that reform in Wisconsin has occurred in all government forms and that most municipalities desiring the managerial results of a professional administration have chosen an adaptation of the mayor-council form. Furthermore, we find that there are few clearly identifiable differences between cities with differing governmental forms.
\end{abstract}

Keywords: Form of Government, Professionalism, Wisconsin

Does municipal government structure matter in Wisconsin and, if so, how and why? Wisconsin's adoption of forms of municipal government differs from the experience in other states. In the United States, the council-manager system has become the most common form of local government, and it is now the prevalent form of choice for adoption by the nation's cities. In Wisconsin, however, the council-manager system has rarely been adopted, and it has often been abandoned. Mayor-council forms still predominate in the state's cities but in recent years a growing number of municipalities have modified their mayor-council governance structures with the creation of the position of a chief administrative officer who reports to the mayor and council. The Wisconsin experience of reform provides important insights regarding the specific role of city government structures. Using Wisconsin findings allows a focus on the relationship between the form of government and performance without the confounding factors such as the wide variations in state laws, controls, electoral arrangements, and restrictions on local municipal autonomy in the United States that could distort a comparative state study (Nelson, 2011). In states that have optional charter laws and home rule such as Wisconsin, the municipalities have greater freedom to design their form of government with their preferences for representative institutions, elected leadership and professional management (Wheeland, Palus, \& Wood, 2014).

This research paper examines the forms of municipal governments of an over 5,00o population in Wisconsin and their relationship to a variety of variables in the areas of socioeconomics, partisanship and election process, decision-making in the governance process, and internal municipal operations. The population size was limited to 5,000 both due to the access to information on smaller populations and the lesser need for some small governments to have professional administrators. The form of government is identified using the three forms of council-manager, mayor-council with a professional administrator, and mayor-council with an elected chief executive.

The literature has found the opposing views that a structural form of government can have an effect on levels of efficiency, innovation, and levels of cooperation in the decision-making process and also that form of government has little impact of these variables. Wisconsin has a high level of mayor-council with administrator forms of government rather than the councilmanager forms common in other states. Wisconsin and Illinois have been particularly impacted Nollenberger, K., \& Simmons, J. (2016). Municipal government structure in Wisconsin: Does form matter? Journal of Public and Nonprofit Affairs, 2(2), 82-100. doi:10.20899/jpna.2.2.82100 
by state laws resulting in more mayor-council-administrator forms than council-manager forms (Nelson, 2011). A city manager usually has more authority in the operations of municipal operations than an administrator depending upon the authority granted to the administrator in the local ordinance creating the position. Whether this alternate approach to professional administration results in similar outcomes as the council-manager form is the topic addressed in this research.

Many writers have stressed the difficulties of comparing cities across states given the wide disparities in the state and local division of labor, the relative levels of comparative city autonomy, and variations in intergovernmental aid (Libert, 1974; Lineberry, 1978). To avoid these difficulties, this study focuses on the impact of municipal structure in one state, despite whatever small effects are lost, with the ability to generalize across cities nationally. Analyzing the forms of government within one state allows the examination of variations in the structure of a single type of municipal government. It also ensures that each municipality is governed by the same statutes and that they share a state culture that is common to all of the municipalities (Carr \& Karuppusamy, 2010).

The three forms of government are compared with 26 variables in the four areas described above. Surveys of all elected officials in the 141 municipalities with a population over 5,000 were conducted in 2011 on the decision-making process in the governance process in their municipalities with a high level of response. Surveys of city clerks and surveys of city managers/administrators also were conducted in 2012 on the forms of government. A database of the variables was created for a statistical analysis of the relationships of the government form and these variables. The forms' impact on the decision-making process and internal municipal operations variables is the focal point of the research paper. Are there significant outcome differences in the decision-making process or internal municipal operations between councilmanager, mayor-council with administrator, and mayor-council with elected chief executive forms?

\section{Local Government Forms: Theoretical and Empirical Context}

An extensive body of literature on the impacts of the structure of city government has been created since the beginning of the reform movement in the early $20^{\text {th }}$ century, with competing perspectives on the significance of forms. Early municipal reformers were convinced that structural change was necessary to improve the performance of municipal governments (Childs, 1952). At the turn of the $20^{\text {th }}$ century, progressives designed the business model of councilmanager government to combat the corruption, partisanship, incompetence, and inefficiency rampant in American cities. The progressives insisted that a nonpolitical professionally appointed administrator overseen by a small elected board would promote the effectiveness of municipal management while at the same time maintaining a transparent, responsive, and accountable local government (Childs, 1952).

Today many critics question the significance of the various elements of reform and whether there is a significant difference between council-manager and mayor-council forms (Carr \& Karuppusamy, 2010; Craw, 2008; Hayes \& Chang, 1990; Jung, 2006; Karuppusamy \& Carr, 2012; Morgan \& Pelissero, 1980). Others have asserted that the adaptations in the traditional mayor-council form have impacted governmental performance without major structural form changes (Frederickson, Johnson, \& Wood, 2004). Others maintain that form still matters (Edwards, 2011; Svara, 2005). Frequently, the adaptations in the council-manager form of government relating to the direct election of the mayor and more district elections in the council 
election process and the adaptation of mayor-council forms to add an administrator are a result of these concerns to make the forms of government responsive as well as more professionally administered. The Adapted City explores these adaptations in an effort to assess their impact on the governmental forms. The authors note that " $[\mathrm{t}] \mathrm{o}$ achieve what we expect, it is essential that our cities be both politically responsive and well managed" (Frederickson et al., 2004, p. 3). The authors argue that the models of government have mingled to the point that it has eliminated the importance of the distinctions between mayor-council and council-manager forms.

While not dismissing some of the findings of the adapted city research, other scholars have taken exception to the diminution of the importance of form of government as a basis for empirical research in the field. One response to the adapted city concept felt that the approach was inductive rather than a practical measure of municipal structure (Carr \& Karuppusamy, 2008). A review of the reform in mayor-council forms found that the creation of the chief administrative officer position in this form had increased in recent decades (Svara, 2005). "The creation of the CAO position adds administrative expertise to the government structure. CAO's share many important characteristics with city manager" (Svara, 2005, p. 502). Overall, Svara felt that the adapted city model discounted the importance of form. Nelson's (2011) work found that the degree of autonomy given by the state government to local governments to modify their forms was related to the adoption choice of form of government. She found that Wisconsin and Illinois were particularly impacted by state laws resulting in more mayor-council with administrator forms than council-manager forms.

The research into the impact of forms of government on various internal operating factors in the local governments has outcomes that are not consistent with each other. Lineberry and Fowler (1967) did research on reformism and public policies in American cities. They related two policy outputs (taxation and expenditure levels of cities) to governmental structural characteristics and socioeconomic characteristics of cities. Their data results showed that reformed cities both spend and tax less than unreformed cities with one exception in the expenditures between partisan and nonpartisan cities. The reformed and nonreformed cities were not markedly different in their demographic variables. But they felt it was important to consider the relative responsiveness of the cities to social cleavages in their community. Their findings indicated that councils after reform "tended to think more of the community as a whole and less of factional interests in making their decisions" (Stone et al., 1940, p. 238).

Morgan and Pelissero (1980) compared 11 cities that changed their governmental form to 11 control cities over an eleven-year period and found that the variations in fiscal behavior were not affected by the change in form. Their research reported that "changes in city government structure have almost no impact on changes in taxing and spending levels" (Morgan \& Pelissero, 1980, p. 1005). They also found that there was no reallocation of funds from one service area to others within the government. However, their time span and number of cities were limited. Another study reviewed the comparable efficiency between the council-manager and mayorcouncil forms of government (Hayes \& Chang, 1990). Using the extensive data available in the International City/County Management Association (ICMA) publication Municipal Year Book, the authors found that there was no statistical difference in efficiency between mayor-council and council-manager forms of government.

This finding of no difference is contradicted by a more recent study funded by the IBM Global Business Services that performed an operations efficiency benchmarking study of 100 cities (Edwards, 2011). This study examined factors such as population, geographic size, collective bargaining, and others to compare with the cities' efficiencies. The authors found that the determining factor in the level of efficiency was management. Cities with council-manager forms 
were almost $10 \%$ more efficient than cities with mayor-council forms of government. In their finding, Svara and Nelson (2008) state that "studies show that when council-manager cities are compared with mayor-council cities the council-manager cities are more likely to have greater efficiency, sounder finances, and stronger management performance" (p. 10).

In a recent study of the relationship of form of government and its relationship to decisionmaking process in local government, it was determined that of the independent variables selected for the analysis (fiscal condition, diversity, income level, population change, partisan elections, method of council election, form of government), government form proved to be the only variable that was significantly related to both perceived levels of conflict and cooperation in the decision-making process (Nelson \& Nollenberger, 2011). Specifically, this study found that communities using the mayor-council form without an administrator, along with those using the mayor-council form with an administrator appointed solely by the mayor, were associated with higher levels of reported conflict and conditions that were less likely to promote cooperation in decision-making than either the council-manager forms or mayor-council with administrator forms when the administrator was jointly appointed by the mayor and council. The existence of a professional administrator appointed jointly by both the mayor and council was the significant factor in this analysis.

As concluded in a recent article on the century of municipal reform in the United States, "Communities and scholars continue to debate the merits of different government structures, the appropriate roles for professionals in governing, and how government can or cannot contribute to solving community problems" (Wheeland et al., 2014, p. 235). The Wisconsin experience may differ from that of other states but continues this debate on difference in government structures. Simmons (2001) makes the following statement: "Another problem confronting the advocates of the council-manager system is that a growing number of cities have adopted many of the efficiency measures associated with the plan, without resorting to the formality of changing to the managerial form" (p. 61). He found few differences between council-manager forms and mayor-council with administrator forms in Wisconsin despite the greater authority given to a manager compared to an administrator. A review of Wisconsin municipalities to assess these findings is the focus of this research.

\section{The Wisconsin Experience}

The Wisconsin Legislature adopted what is referred to as a general charter law for cities and villages in Wisconsin. Chapter 61 of the Wisconsin statutes deal with villages; Chapter 62 and Chapter 64 deal with cities. A charter ordinance is used by cities and villages to adopt the choice of statutory form of government provided by these chapters. Chapter 61 on villages designates the title of chief elected official as the President of the Village Board. Chapter 62 for cities establishes the mayor-council form of government. Chapter 64 allows for the city manager plan and the commission government plan. There are no municipalities using the commission plan. Chapter 64 provides for municipal wide election of the city council, the election of a council president by the city council from among its members (no mayor position), and the appointment powers to boards and committees by the city manager. The president of the council has no veto authority. The City Manager under Chapter 64 has the authority for appointment of department heads (except when a police or fire commission exists for those positions) and the recommendation of the annual budget. Under the mayor-council form, the city or village can adopt an ordinance creating an administrator position and define the authority of that position. Cities and villages adopting an administrator form differ in the authority given to the position from very little authority to a level virtually equal to a city manager. In addition to these statutes 
on the forms of local governance, the Constitution of the State of Wisconsin provides for home rule powers for cities and villages. Chapter 66.0101 of the Wisconsin statutes allows cities and villages to adopt alternative legislation by charter ordinance for issues that are not of uniform statewide concern (League of Wisconsin Municipalities, 2002).

As noted by the Wisconsin Taxpayers Alliance [WTA](2005), the major reason for the limited adoption of the city manager plan is the feeling that the position as outlined in Chapter 64 is "too strong." A remedy to these features can be a charter ordinance amendment to the statutory provisions. A council-manager form municipality can create an office of mayor, have district election of council members, and give the mayor the appointment authority of the boards and commissions under a charter ordinance. However, the flexibility built into the statutes for the mayor-council form are more lenient and "undoubtedly slowed the growth of the manager form." (Donoghue, 1980, p. 158). Paddock and Olson (1993) note that "communities choose to create Administrator rather than Manager position because they do not want to give up the executive power of the Mayor or President" (p. 5). The authors concluded that the administrator position has brought professionalism to the cities and villages that added the position.

\section{Hypotheses}

The past research noted in the preceding sections describes the opposing views on whether the form of government has an impact of the decision-making process in government, efficiency of the municipal operations, and levels of financial conditions. Due to the Wisconsin statutes for form of government, Wisconsin is unique in the adoption of significantly more mayor-council with administrator forms of government than council-manager forms due to the ease of adopting ordinances outlining the form under mayor-council versus home rule charter ordinances amending the statutory provisions on the council-manager form when it is legally justified and not of state-wide concern. While this is unique to Wisconsin, the adoption of an administrator under the mayor-council form does happen in other states but not with the percentage of adoptions as in Wisconsin. This research on the Wisconsin forms of government and their relationship to the decision-making process, efficiency of municipal operations and levels of financial condition provides clarification of the impact of forms of government in Wisconsin and may provide some insights on the impact of the forms in other states.

Based on the research to date on the impact of forms of government, we have developed three hypotheses.

$H_{1}$ : The levels of conflict and cooperation will differ significantly by form of government with strong mayor-council forms having higher levels of conflict and lower levels of cooperation than forms having a manager/administrator.

As noted in the previous sections, previous research on a national level for municipalities between 50,000 and 250,000 population has shown that a form of government is related to levels of conflict and cooperation with municipalities without an administrator having higher levels of conflict and lower levels of cooperation in the decision-making process (Nelson \& Nollenberger, 2011).

$\mathrm{H}_{2}$ : General government expenditures per capita and tax rate per \$1,ooo assessed value will be lower in forms of government with a manager/administrator. 
Table 1. Combined Wisconsin Forms of Government

\begin{tabular}{lcccc}
\hline \multicolumn{1}{c}{ Forms } & City & Village & Total & $\%$ \\
\hline Council-Manager & 10 & 8 & 18 & $12.8 \%$ \\
Mayor-Council-Administrator Appointed/Approved & 58 & 35 & 93 & $66.0 \%$ \\
Strong Mayor-Council without Administrator & 24 & 0 & 24 & $17.0 \%$ \\
Weak Mayor/-Council without Administrator & 4 & 2 & 6 & $4.2 \%$ \\
\hline Total & 96 & 45 & 141 & $100 \%$ \\
\hline
\end{tabular}

Also as noted in previous sections, past research is mixed on the level of spending in forms with administrators with some showing no differences and other findings showing more efficiency in spending levels (Edwards, 2011; Hayes \& Chang, 1990; Lineberry \& Fowler, 1967; Morgan \& Pelissero, 1980; Stone et al., 1940; Svara \& Nelson, 2008).

$H_{3}$ : The financial condition of the city as measured by the bond ratings of the municipality will be stronger in forms of government with a professional manager/administrator.

Similar to the hypothesis 2, there are some findings that the financial condition of cities with professional administrators is better than other cities due to more efficiency in the operations (Svara \& Nelson, 2008).

\section{Data and Empirical Strategy}

The form of government is identified using the council-manager form, mayor-council with a professional administrator form, and mayor-council with an elected chief executive form. After further review, the 30 mayor-council forms with an elected chief executive form was further refined to distinguish those with a strong mayor/president (24 cities) and those with a weak mayor/president (six cities) based on their defined responsibilities. Subdividing the mayorcouncil cities is a common approach in making a distinction in the formal powers of the mayor (DeSantis \& Renner, 2012; Karuppusamy \& Carr, 2012). The refinement was created by reviewing whether the appointment of department heads and recommendation of budget authority was given to the mayor/president and if there was a full- or part-time salary level for that position. All of the Wisconsin municipality forms with population of over 5,000 were compared against a number of independent variables.

To ensure that the forms for each municipality were correctly identified, a review of the ICMA's form of government recognition and the State of Wisconsin Blue Book was undertaken. An electronic administered survey of city clerks in Wisconsin was conducted for additional clarification of the form. Whenever a difference occurred between the sources, the form of government was further researched for that municipality on its web site reviewing the enabling ordinances on the form. Direct contact was made with municipal officials whenever questions persisted.

As shown in table $1,78.8 \%$ of Wisconsin cities over 5,000 population have a professional manager or administrator. Yet, only $12.8 \%$ of those are council-manager forms of government and the remaining $66.0 \%$ are mayor-council with an administrator appointed or approved by the city council/village board. By contrast nationwide, 53.0\% of U.S. municipalities over 5,000 population have a council-manager form of government (ICMA, 2011). 
Table 2. Conflict and Cooperation Variables

\begin{tabular}{|c|c|c|}
\hline Tension & Variables & Effect \\
\hline \multirow{3}{*}{$\begin{array}{l}\text { Relationships among } \\
\text { elected officials }\end{array}$} & Number of factions on council & > conflict \\
\hline & Amiability of mayor-council relations & $>$ cooperation \\
\hline & Trust in and support of mayor by council & $>$ cooperation \\
\hline \multirow[t]{2}{*}{ Roles of elected officials } & $\begin{array}{l}\text { Involved in long-term goal setting and broad } \\
\text { oversight }\end{array}$ & $\begin{array}{l}>\text { cooperation } \\
>\text { conflict }\end{array}$ \\
\hline & Involved in minor administrative details & \\
\hline \multirow{3}{*}{$\begin{array}{l}\text { Quality of performance of } \\
\text { elected officials }\end{array}$} & Effective long-term goal setting & $>$ cooperation \\
\hline & $\begin{array}{l}\text { Adequate performance feedback--council to } \\
\text { CEO/CAO }\end{array}$ & $\begin{array}{l}>\text { cooperation } \\
>\text { conflict }\end{array}$ \\
\hline & Focus on important issues in the community & \\
\hline \multirow{4}{*}{$\begin{array}{l}\text { Quality of performance of } \\
\text { chief executive; manager, } \\
\text { CAO, or mayor/staff in } \\
\text { mayor-council } \\
\text { governments }\end{array}$} & Accomplish goals set by council & $>$ cooperation \\
\hline & Provide Alternatives and analysis of policies & $>$ conflict \\
\hline & Have high standards of personal conduct & $>$ conflict \\
\hline & & \\
\hline
\end{tabular}

Based on other research done on the relationships of independent variables to government form, the variables to which the forms outlined above were compared are shown in the following table along with the averages in Wisconsin municipalities. The socioeconomic variables serve as control variables.

In the government decision-making process category, the levels of conflict in the governance process were measured by using a survey instrument sent to all elected officials in the 141 municipalities. The survey instrument is a modified version of the one used in previous research, which measured levels of conflict and cooperation in the governance process in United States' cities (Nelson \& Nollenberger, 2011). The survey was undertaken to gain insight into how elected officials perceive their own roles and those of other officials and levels of confrontational and cooperative behavior in the decision-making process in their municipalities. The dependent variables were measured through the construction of a set of survey questions designed to examine three areas (tensions) in city government that are likely sources of greater or lesser levels of conflict or cooperation (see table 2 and appendix).

Each question was scored according to how the answer related to the tensions in the process; the scoring was done on a zero-to-one basis, with zero being the low and one being the high level of conflict or cooperation. An index variable was created for each survey instrument. An example of some of the survey questions and the scoring is shown in the appendix. The resulting database includes the scores for all responding city mayors, village board presidents, city council members, and village board members with averages for each municipality.

In the socioeconomic category, nine variables are shown in table 3 with the average for eight of these variables. The 141 municipalities in the database also were categorized by their location as a central city or a suburban city to monitor expenditure and/or form of government differences between central and suburban cities. There were 84 central cities and 57 suburban cities. These socioeconomic variables may provide insight into the relationship to the adoption of form of government.

In the partisanship and election process category, 92 (65.2\%) of the municipalities have district elections and 49 (34.8\%) do not (Wisconsin Legislative Reference Bureau [WLRB], 2009). The average Republican vote total in the 2010 gubernatorial election was $54.4 \%$ (WLRB, 2009). The 
Table 3. Variables Definitions

\begin{tabular}{|c|c|c|}
\hline Variable & Description (Source) & Average \\
\hline \multicolumn{3}{|l|}{ Socioeconomic Variables } \\
\hline Population 2010 & $\begin{array}{l}\text { Census } 2010 \text { population data, range 5,000 and up } \\
\text { (Census Bureau, 2013) }\end{array}$ & 24,354 \\
\hline Community Growth & $\begin{array}{l}\text { Population growth or decline 2000-2010 (Census } \\
\text { Bureau, 2013) }\end{array}$ & $10.6 \%$ \\
\hline Median Household Income & $\begin{array}{l}\text { Income level: median family income (Census Bureau, } \\
\text { 2013) }\end{array}$ & $\$ 55,532$ \\
\hline Diversity Majority & $\begin{array}{l}\text { White/non-white majority in the city (Census Bureau, } \\
\text { 2013) }\end{array}$ & $88.8 \%$ \\
\hline Education Level & $\begin{array}{l}\text { Percentage of college graduates (Census Bureau, } \\
\text { 2013) }\end{array}$ & $29.2 \%$ \\
\hline Crime Index & Crime index (Federal Bureau of Investigation 2012) & 2868 \\
\hline Unemployment & $\begin{array}{l}\text { \% unemployment in the city/village (Census Bureau, } \\
\text { 2013) }\end{array}$ & $6.2 \%$ \\
\hline Central City/Suburban & Central city vs. suburban city & \\
\hline Poverty Level & $\begin{array}{l}\text { \% below poverty level in the municipality (Census } \\
\text { Bureau, 2013) }\end{array}$ & $10.2 \%$ \\
\hline \multicolumn{3}{|l|}{ Partisanship \& Election Process } \\
\hline District or Municipality Wide & Election type: district vs. at large (WLRB, 2009) & \\
\hline City Council/Board Size & Size of city council or village board (WLRB, 2009) & \\
\hline Republican Vote \% & $\begin{array}{l}\text { Republican vote \% in } 2010 \text { Governor election (WLRB, } \\
\text { 2009) }\end{array}$ & \\
\hline Difference in Partisan Vote \% & $\begin{array}{l}\text { Vote Difference } 2010 \text { Governor by } 5 \% \text { groups (WLRB, } \\
\text { 2009) }\end{array}$ & \\
\hline \multicolumn{3}{|l|}{ Decision Making in Governance } \\
\hline Levels of Conflict & Conflict level index from surveys of elected officials & \\
\hline Levels of Cooperation & $\begin{array}{l}\text { Cooperation level index from surveys of elected } \\
\text { officials }\end{array}$ & \\
\hline \multicolumn{3}{|l|}{ Internal Municipal Operations } \\
\hline Financial Condition of City & $\begin{array}{l}\text { Bond ratings - Moody's, Standard \& Poor's, Fitch - } 1 \\
\text { to } 10\end{array}$ & \\
\hline Debt per Capita & City debt per capita (WTA 2012) & $\$ 1,615$ \\
\hline Tax Rate per $\$ 1,000$ & Tax rate per $\$ 1,000$ assessed value (WTA 2012) & $\$ 6.83$ \\
\hline Taxes per Capita & Taxes per capita (WTA 2012) & $\$ 512.14$ \\
\hline Operating Costs per Capita & $\begin{array}{l}\text { Total operating costs in municipality per capita (WTA } \\
\text { 2012) }\end{array}$ & $\$ 804$ \\
\hline $\begin{array}{l}\text { General Government } \\
\text { Expenditures }\end{array}$ & $\begin{array}{l}\text { General government costs per capita (University of } \\
\text { Wisconsin Extension, 2014) }\end{array}$ & $\$ 116.07$ \\
\hline Public Safety Expenditures & $\begin{array}{l}\text { Public safety costs per capita (University of Wisconsin } \\
\text { Extension, 2014) }\end{array}$ & $\$ 255.88$ \\
\hline Fire Expenditures & $\begin{array}{l}\text { Fire costs per capita (University of Wisconsin } \\
\text { Extension, 2014) }\end{array}$ & $\$ 107.01$ \\
\hline Public Works Expenditures & $\begin{array}{l}\text { Public works costs per capita (University of } \\
\text { Wisconsin Extension, 2014) }\end{array}$ & $\$ 166.28$ \\
\hline Human/Health Services & $\begin{array}{l}\text { Human/health services costs per capita (University of } \\
\text { Wisconsin Extension, 2014) }\end{array}$ & $\$ 14.33$ \\
\hline Culture/Parks \& Rec Costs & $\begin{array}{l}\text { Culture/parks\& recreation costs per capita } \\
\text { (University of Wisconsin Extension, 2014) }\end{array}$ & $\$ 128.48$ \\
\hline
\end{tabular}


Table 4. Difference in Partisan Vote

\begin{tabular}{cc}
\hline \hline Vote \% Difference & \# of Municipalities \\
\hline $0-5 \%$ & 26 \\
$5-10 \%$ & 24 \\
$10-15 \%$ & 22 \\
$15-20 \%$ & 11 \\
$20-25 \%$ & 12 \\
$25-30 \%$ & 13 \\
$30-35 \%$ & 7 \\
$35-40 \%$ & 11 \\
$40-45 \%$ & 5 \\
$45-50 \%$ & 7 \\
$50-55 \%$ & 3 \\
$55-60 \%$ & 3 \\
\hline
\end{tabular}

lowest Republican vote percentage in the 141 municipalities was $22.1 \%$ and the highest was 79.9\%. The number of cities for the difference in partisan vote percentage allocated by $5 \%$ intervals is shown in table 4. These election results are included as a measure of how conservative a community is and if that has any relationship to the form of government.

Table 5 shows the average levels of conflict and cooperation index variables. Of the 141 municipalities surveyed, there were three municipalities with no response from the elected officials surveyed and nine municipalities with only one response. The average of $45.2 \%$ shown below is a good response level. The response rate for council-manager form cities was $48.0 \%$, for mayor-council with an administrator $46.2 \%$ and for mayor-council without an administrator was $38.8 \%$.

The number of cities and percentage of the total cities in the financial condition rankings as measured by bond ratings is shown in table 6. Ranking is from best condition (1) to lowest (9).

The information in table 2 shows the average socioeconomic and internal operational costs of the municipalities. The average expenditures in the operational areas may reflect different priorities of the municipalities that are also a reflection of their choice of form of government.

All of the 26 variables described above are potentially related to government form. The next section analyzes which of these variables proved to be significant using regression analyses. Multiple regressions were conducted on the variables in the database described above to assess the significance of the relationships between the forms of government and these factors. Multiple regression is a statistical technique used to test the robustness of the bivariate relationships among variables when they are controlled for other variables. The multiple regression modeling tries to control for all identifiable independent variables that are affecting the dependent variables and to assess the relevance of those effects. The regression coefficients are interpreted for their effects on the dependent variables while controlling for the effect of all the independent variables included in the regression. Regression analysis shows the significance of the relationships between the independent variables and the dependent variables, with lower scores being more significant than higher scores. Social science research uses .05 and .10 as the levels of statistical significance for relationships to exist. The statistical analysis as reflected in the adjusted $R^{2}$ reflects the net effect of all the variables that are not included in the model. The $R^{2}$ also is called the coefficient of determination and is interpreted as "the percentage of variation in the dependent variable that is explained by the independent variable" (Berman, 2002, p. 122). In public administration research, $R^{2}$ values below 0.20 are considered weak, 
Table 5. Conflict and Cooperation Averages

\begin{tabular}{ccccccc}
\hline $\begin{array}{c}\text { \% Survey } \\
\text { Respondents }\end{array}$ & $\begin{array}{c}\text { Cooperation } \\
\text { Index } \\
\text { Average }\end{array}$ & $\begin{array}{c}\text { Cooperation } \\
\text { Minimum }\end{array}$ & $\begin{array}{c}\text { Cooperation } \\
\text { Maximum }\end{array}$ & $\begin{array}{c}\text { Conflict } \\
\text { Index } \\
\text { Average }\end{array}$ & $\begin{array}{c}\text { Conflict } \\
\text { Minimum }\end{array}$ & $\begin{array}{c}\text { Conflict } \\
\text { Maximum }\end{array}$ \\
\hline $45.2 \%$ & 0.7712 & 0.2657 & 0.9881 & 0.2247 & 0.0204 & 0.5705 \\
\hline
\end{tabular}

Table 6. Financial Condition Rankings

\begin{tabular}{lccccccccc}
\hline \hline \multicolumn{1}{c}{ Rank } & 1 & 2 & 3 & 4 & 5 & 6 & 7 & 8 & 9 \\
\hline Cities & $6-$ & $15^{-}$ & $48^{-}$ & $41^{-}$ & $25^{-}$ & $0-0 \%$ & $3^{-}$ & $1^{-.} .7 \%$ & $2-$ \\
(\% of Total) & $4.3 \%$ & $10.6 \%$ & $34.0 \%$ & $29.1 \%$ & $17.7 \%$ & & $2.1 \%$ & & $1.4 \%$ \\
\hline
\end{tabular}

while those between 0.20 and 0.40 are considered moderate (Berman, 2002). Any value above 0.40 is considered strong.

\section{Findings: Analysis of Form of Government to Variables}

Of the 141 municipalities in over 5,000 populations in Wisconsin, the mayor-council with administrator form is dominant consisting of $66.0 \%$ of the municipalities. The council-manager form is $12.8 \%$ of the municipalities with the remaining operating under a strong mayor form (17.0\%) or operating without an executive officer (4.2\%). The independent variables described above in the areas of socioeconomic variables, partisanship, and election process variables, decision-making in governance variables, and internal municipal operations variables are considered in this research to ascertain any relationship between the form of government and these variables.

The regression analysis used the 26 variables, of which 21 are continuous, three are ordinal, and two are dichotomous variables. The regressions used form of government as one of the independent variables when the dependent variable may be caused by form and/or other variables. In the initial regression, the independent variables of district or at-large elections and size of council had significance levels of .oo. The Wisconsin statutes sets the requirement for atlarge elections in Villages and district elections in cities and also sets the size of the elected body resulting in multicollinearity although these variables can be changed by home rule charter ordinances in the municipalities. Because the significance of these two independent variables is set by the statutes, they were eliminated from further analysis.

The form of government-dependent variable has the four forms, as described in the previous section: council-manager, mayor-council with administrator, strong mayor-council without administrator, and weak mayor-council without administrator. A further refinement in the regression analysis combined the council-manager form with the mayor-council with administrator form to measure the impact of having a professional administrator or not. This regression analysis used the three forms of government as the independent variable: forms with a professional administrator, the strong mayor-council form, and the weak mayor-council form.

Regressions were performed with each of the decision-making processes, internal municipal operations, socioeconomic, and partisanship and election process factors as the dependent variables. In addition, to meet the assumptions of multiple regression, the form of government was re-coded as a dummy variable with one of the forms acting as the reference group. Regressions were performed making the decision-making in the governance process and internal municipal operations variables as the dependent variable to assess whether form of government was a significant relationship to these factors. The dependent variables of conflict, 
Table 7. Regression of Conflict and Cooperation

\begin{tabular}{lcc}
\multicolumn{1}{c}{ Variables } & Conflict & Cooperation \\
\hline Strong Mayor & $0.257^{* *}$ & $-0.198^{*}$ \\
Weak Mayor & $0.171^{*}$ & -0.117 \\
Financial Condition & 0.010 & -0.018 \\
Population 2010 & -0.008 & -0.051 \\
Growth 2000-2010 & 0.062 & -0.049 \\
Median House Income & -0.283 & 0.210 \\
Diversity Majority & -0.097 & 0.086 \\
Central or Suburb & -0.145 & 0.117 \\
Education Level & $0.289^{*}$ & -0.149 \\
\% Unemployed Rate & 0.084 & -0.057 \\
Crime Index & -0.010 & 0.035 \\
Difference Partisan Vote & -0.136 & 0.152 \\
\hline Adjusted $R^{2}$ & 0.163 & 0.109 \\
$F$ & $2.027^{*}$ & 1.272 \\
\hline
\end{tabular}

Values shown are standardized regression coefficients.

${ }^{*} \mathrm{p}<.05 ;{ }^{* *}<.01 ;{ }^{* * * *}<.001$

Table 8. Regression of General Government

Expenditures and Tax Rate per $\$ 1,000$

\begin{tabular}{lcc}
\hline \multicolumn{1}{c}{ Variables } & Conflict & Cooperation \\
\hline Strong Mayor & $-0.193^{*}$ & $0.143^{*}$ \\
Weak Mayor & -0.101 & -0.034 \\
Council-Manager & -0.158 & 0.020 \\
Financial Condition & 0.073 & 0.088 \\
Population 2010 & $0.443^{* * *}$ & -0.065 \\
Growth 2000-2010 & -0.169 & $-0.230^{* *}$ \\
Median House Income & 0.164 & $-0.241^{*}$ \\
Diversity Majority & 0.125 & -0.057 \\
Central or Suburb & 0.042 & $-0.211^{* *}$ \\
Education Level & 0.026 & 0.018 \\
\% Unemployed Rate & 0.168 & 0.088 \\
Crime Index & 0.069 & 0.084 \\
Difference Partisan Vote & 0.121 & $0.209^{* * *}$ \\
\hline Adjusted R-squared & 0.255 & 0.537 \\
$F$ & $3.342^{* * *}$ & $11.351^{* *}$ \\
\hline Values &
\end{tabular}

Values shown are standardized regression coefficients.

${ }^{*} \mathrm{p}<.05 ;{ }^{* *}<.01 ;{ }^{* * *}<.001$

cooperation, general governmental expenditures, tax rate per $\$ 1,000$, and financial condition yielded some results of interest relating to the form of governments. These five variables were used as dependent variables and had a significant relationship to the form of government.

In the regression with conflict as the dependent variable (table 7), the strong mayor form of government, weak mayor form, and education level were significant at the 0.05 level. The level of conflict in the strong and weak mayor form is significantly higher (0.01 and 0.05) than in the forms with an administrator. The independent variable of professional administrator or not served as the dummy variable on forms of government. Compared with the professional administrator or not, the strong and weak mayor form had significantly more conflict. 
Table 9. Financial Condition

\begin{tabular}{lc}
\hline \multicolumn{1}{c}{ Variables } & Measurement \\
\hline Strong Mayor & -0.140 \\
Weak Mayor & 0.139 \\
Council-Manager & 0.066 \\
Population 2010 & $-0.199^{*}$ \\
Growth 2000-2010 & 0.074 \\
Median House Income & -0.176 \\
Diversity Majority & 0.068 \\
Central or Suburb & 0.035 \\
Education Level & $-0.316^{* *}$ \\
\% Unemployed Rate & $0.234^{*}$ \\
Crime Index & -0.130 \\
Difference Partisan & 0.103 \\
Vote & \\
\% Below Poverty Level & -0.030 \\
\hline Adjusted R-squared & 0.401 \\
F & $5.572^{* * *}$ \\
\hline Values shown are standardized regression \\
coefficients. & \\
${ }^{*}$ p <.05; ${ }^{* *}<.01 ; * *<.001$ &
\end{tabular}

In the regression with cooperation as the dependent variable (table 7), the independent variable, professional administrator or not, served as the dummy variable. The only independent variable of significance was strong mayor, which was negatively related to cooperation. The strong mayor form has less cooperation in the decision making process than the other forms. The $R^{2}$ at 0.11 was low for a regression.

In the regression with a dependent variable of general governmental expenditures per capita (table 8), the four forms were used separating the professional administrator into the councilmanager forms and the mayor-council with an administrator form due to the differences in the average general government expenditures between the two forms. The dummy variable was the mayor-council with an administrator. The strong mayor independent variable was significant at 0.03 and population at 0.00. Population is directly related to the strong mayor form with strong-mayor cities being almost three times the average of all other cities. This is due mainly to the fact that the state's three largest cities-Milwaukee, Madison, and Green Bay-do not have an administrator position. The strong mayor form (at a significance of 0.03) and the councilmanager forms (at a significance level of 0.06) had less general government expenditures per capita than the mayor-council forms with an administrator. The $R^{2}$ of 0.26 is an acceptable level.

The regression with the tax rate per $\$ 1,000$ as the dependent variable (table 8 ) had a high level $R^{2}$ of 0.54 . The independent variables of growth 2000-2010, central or suburban municipality, difference rating for voting in the 2010 gubernatorial election, republican vote \%, strong mayor, and median income were significant at the 0.05 level. The strong mayor form was significant at the .04 level showing a higher level of tax rate in that form.

A regression was performed with financial condition (table 9) as a dependent variable with the four forms of government and other external factors. The mayor-council with an administrator form was the dummy variable. The strong mayor form of government had a lower bond rating score (stronger financial condition) at a significance rating of 0.07. The weak mayor form of 
Table 10. Averages by Form of Government

\begin{tabular}{lccccc}
\hline \multicolumn{1}{c}{ Form of Government } & Cooperation & Conflict & $\begin{array}{c}\text { General } \\
\text { Government } \\
\text { Expenditures }\end{array}$ & $\begin{array}{c}\text { Tax Rate } \\
\text { per } \\
\$ 1,000\end{array}$ & $\begin{array}{c}\text { Financial } \\
\text { Condition } \\
\text { Rating }\end{array}$ \\
\hline Council-Manager & 0.7662 & 0.1857 & $\$ 106.71$ & $\$ 7.11$ & 3.50 \\
Mayor-Council with CAO & 0.7191 & 0.2133 & $\$ 118.70$ & $\$ 6.55$ & 3.76 \\
Professional Administrator & 0.7269 & 0.2087 & $\$ 116.76$ & $\$ 6.64$ & 3.72 \\
Strong Mayor & 0.6560 & 0.2808 & $\$ 117.13$ & $\$ 7.74$ & 3.04 \\
Weak Mayor & 0.6569 & 0.2247 & $\$ 99.00$ & $\$ 6.62$ & 5.00 \\
\hline
\end{tabular}

138 municipalities provided responses from at least one elected officials with an overall $45.2 \%$ response

rate for the conflict/cooperation survey.

governments had a higher bond rating score (worse financial condition) at a significant level of 0.07. Other independent significant variables were population at 0.07 , education level at 0.00 , and the unemployed rate at 0.02 . The $R^{2}$ level at 0.40 is high.

\section{Discussion}

Hypothesis 1 dealt with the decision-making process, and the results of the regressions showed the hypothesis to be confirmed. The level of conflict in strong mayor-council without an administrator is significantly higher than in a municipality with an administrator at a .01 significance level. The level of cooperation in strong mayor-council was significantly lower than municipalities with an administrator at a 0.04 significance level. This finding verifies other research studies that found conflict were related to form of government (Nelson \& Nollenberger, 2011). In the previous research of cities between 50,000 and 250,000 in population, Green Bay had the highest level of conflict of the 165 responding cities in the United States. It ranked third in this study behind La Crosse and Sheboygan, which were not part of the previous research due to size. The averages of conflict and cooperation combining the forms as done in the regressions above are shown in table 10.

Hypothesis 2 projected that the tax rate per $\$ 1,000$ and the general governmental expenditures would be less in forms of government with a professional administrator. The regression results showed partial substantiation of this hypothesis. As shown in table 10, the level of general government expenditures is higher in the strong mayor-council municipalities at an average of $\$ 117.13$ compared with $\$ 116.76$ in municipalities with an administrator. When the administrative forms are separated out into council-manager and mayor-council with an administrator, the mayor-council with an administrator form was significantly higher on at $\$ 118.70$ than the council-manager and strong mayor form. The council-manager form was significantly lower (at 0.06 level) at $\$ 106.71$. Yet the tax rate per $\$ 1,000$ is significantly higher in strong mayor forms than in the mayor-council-administrator form at 0.04 significance. The strong mayor form has a tax rate of $\$ 7.74$ compared with the $\$ 6.55$ in the mayor-counciladministrator forms.

Hypothesis 3 projected that the financial condition of the city would be stronger in forms with a professional manager/administrator. The results of the regression showed that to be the opposite with strong mayor forms having a stronger level of financial condition. The financial condition of the municipalities as measured by the bond ratings of the municipality are not significantly different at the 0.05 significance level, but the strong mayor form is better than the mayor-council with an administrator form at the 0.07 level of significance. The weak mayor 
form is worse than the mayor-council with an administrator form at the 0.07 level of significance.

\section{Conclusion}

This research analyzed the impact of forms of government in the Wisconsin experience where reform has taken the direction of more adoption of an administrator in the mayor-council form rather than council-manager forms. Wisconsin is one of the handful of states that allows municipalities to adapt the mayor-council form to more closely resemble the council-manager form. The results of the analysis on variables related to form of government in Wisconsin did yield some results as expected from past studies and some new findings on the impact of form of government.

The levels of conflict/confrontation in the decision-making process is significantly higher in strong mayor forms than in forms with an administrator. The levels of cooperation in the decision-making process is significantly lower in strong mayor forms. It can be stated that Wisconsin cities without an administrator have some of the highest levels of confrontation/conflict in the governance process in the United States. The existence of a professional administrator was the significant factor with both council-manager and mayorcouncil, with an administrator form having significantly less conflict than the strong mayor form. The highest conflict index in the state was in La Crosse, which also had the lowest index for cooperation. In mayor-council forms of government, Sheboygan and Green Bay had a high conflict index. Subsequent to the survey, Sheboygan adopted the mayor-council with an administrator form of government. Additional research on the impact of the conflict and cooperation in the decision-making process on the quality of the decisions would be of value to assess the impact of this finding. A qualitative analysis of municipalities with differing scores would be of value to assess the impact.

The independent variables of total operating costs per capita, general government expenditures per capita, debt per capita, taxes per capita, and tax rate per $\$ 1000$ of assessed valuation are indicators of efficiency and economy in an organization. As noted earlier, the results of previous studies have shown different results on whether the form of government is associated with the indicators of efficiency and economy in government. The results of this research show that the general government expenditures per capita for the strong mayor and council-manager forms were significantly lower than mayor-council with an administrator form. This finding shows that strong mayor forms are both less costly on general expenses than the mayor-council forms with administrators and more costly than the forms with managers. Yet, the strong mayor form had a significantly higher tax rate per $\$ 1,000$ of assessed value than the mayor-council with administrator municipalities. The differences between council-manager and mayor-council with an administrator in general governmental expenditure per capita may be due to the structure of the forms and deserves additional research to assess the differences. None of the other efficiency measures were significantly related to the form of government. The strong mayor forms in Wisconsin appear to have adopted many of the efficiencies of the reform movement without a change in governmental form. Further research into the operations of strong mayor forms in Wisconsin could add to this finding. We recommend comparable case study research to either confirm or modify our findings concerning the limited impact of urban structure on policy.

The comparisons between council-manager and mayor-council-administrator forms does not show any major difference in the socioeconomic factors, decision-making process, partisanship or election process variables, and on just a few in the internal operations factors. The reformed 
municipalities in Wisconsin mainly have adopted the mayor-council with administrator form instead of the council-manager form. This adaptation of the mayoral form has produced most of the desired results expected by the reform movement. While the council-manager form of government constitutes only a small minority in Wisconsin compared with over half of U.S. cities, the adoption of a professional administrator in the mayor-council form constitutes twothirds of state municipalities compared with one in six cities nationwide. Thus, with the adoption of various forms of adapted professionalism in its cities, Wisconsin has managed to achieve many of the substantive objectives of municipal reform without all of its formal structural features. Future studies need to review state laws in other states and the impacts that the laws have on the adoption of the form of governments. The ability to adapt the mayorcouncil form to add professional administrator should be reviewed as well as the nature of the legal process for this adaptation.

\section{Disclosure Statement}

The authors declare that there are no conflicts of interest that relate to the research, authorship, or publication of this article.

\section{References}

Berman, E. M. (2002). Essential statistics for public managers and policy analysts. Washington, DC: CQ Press.

Carr, J. B., \& Karuppusamy, S. (2008). Beyond ideal types of municipal structure: Adapted cities in Michigan. American Review of Public Administration, 39, 304-321. doi:10.1177/0275074008319217

Carr, J. B., \& Karuppusamy, S. (2010). Reassessing the link between city structure and fiscal policy: Is the problem poor measures of governmental structure? American Review of Public Administration, 40, 209-228. doi:10.1177/0275074009334641

Childs, R. S. (1952). Civic victories. New York, NY: Harper \& Brothers.

Census Bureau. (2013). Quick facts: United States. Retrieved from http://quickfacts.census.gov/qfd/states/55/5506350.html

Craw, M. (2008). Taming the local leviathan: Institutional and economic constraints on municipal budgets. Urban Affairs Review, 43, 663-690. doi:10.1177/1078087407311588

DeSantis V. S., \& Renner, T. (2002). City government structures: An attempt at clarification. State and Local Government Review, 34, 95-104. doi:10.1177/0160323X0203400202

Donoghue, J. R. (1980). Local government in Wisconsin. In H. R. Theobald \& P. V. Robbins (Eds.), 1979-1980: State of Wisconsin blue book (pp. 95-312). Madison, WI: Department of Administration.

Edwards, D. (2011). Smarter, faster, cheaper: An operations efficiency benchmarking study of 100 American cities. Somers, NY: IBM Global Services.

Federal Bureau of Investigation. (2013). Uniform Crime Reporting. Retrieved from http://www.fbi.gov/about-us/cjis/ucr/ucr

Frederickson, H. G., Johnson, G. A., \& Wood, C. H. (2004). The adapted city: Institutional dynamics and structural change, Armonk, NY: M. E. Sharpe.

Hayes, K., \& Chang, S. (1990). The relative efficiency of city manager and mayor-council forms of government. Southern Economic Journal, 57, 167-177. doi:10.2307/1060487

International City/County Management Association. (2011). Stereotypes in council-manager governments. Retrieved from 
http://icma.org/en/BlogPost/141/Stereotypes in CouncilManager Governments part 3 of 5

Jung C. (2006). Forms of government and spending on common municipal functions: A longitudinal approach. International Review of Administrative Sciences, 72, 363-376. doi:10.1177/0020852306068016

Karuppusamy, S., \& Carr, J. B. (2012). Interjurisdictional competition and local public finance: Assessing the modifying effects of institutional incentives and fiscal constraints. Urban Studies, 49, 1549-1569. doi:10.1177/0042098011415435

League of Wisconsin Municipalities. (2002). Handbook for Wisconsin municipal officials. Madison, WI: League of Wisconsin Municipalities.

Liebert, R. J. (1974). Municipal functions, structures, and expenditures: A reanalysis of recent research. Social Science Quarterly, 54(4), 765-783.

Lineberry, R. L. (1978). Reform, representation and policy. Social Science Quarterly, 59(1), 173177.

Lineberry, R. L., \& Fowler, E. P. (1967). Reformism and public policies in American cities. American Political Science Review, 61, 701-716. doi:10.2307/1976089

Morgan, D. R., \& Pelissero, J. P. (1980). Urban policy: Does political structure matter? American Political Science Review, 74, 999-1006. doi:10.2307/1954319

Morgan, D. R., \& Watson, S. S. (1992). Policy leadership in council-manager cities: Comparing mayor and manager. Public Administration Review, 52, 438-446. doi:10.2307/976803

Nelson, K. L. (2011). State-level autonomy and municipal government structure: Influence on form of government outcomes. American Review of Public Administration, 41, 542-561. doi:10.1177/0275074010382134

Nelson, K. L., \& Nollenberger, K. (2011). Conflict and cooperation in municipalities: Do variations in form of government have an effect? Urban Affairs Review, 47, 696-720. doi:10.1177/1078087411409129

Paddock, S. C., \& Olson, J. P. (1993). The municipal administrator in Wisconsin. Madison, WI: League of Wisconsin Municipalities.

Simmons, J. (2001). Whither local government reform? The case of Wisconsin. National Civic Review, 9o, 45-62. doi:10.1002/ncr.90105

Stone, H., Price, D., \& Stone, K. (1940). City manager government in the United States. Chicago, IL: Public Administration Services.

Svara, J. H. 2005. Exploring Structures and Institutions in City Government. Public Administration Review 65 (4): 500-06.

Svara, J. H., \& Nelson, K. L. (2008). Taking stock of form and structure in county government. Public Management, 9o(7), 6-15.

University of Wisconsin Extension. (2014). Graphing revenues, expenditures and taxes program (GREAT). Retrieved from http://lgc.uwex.edu/Finance/great.html

Wheeland, C. M., Palus, C. K., \& Wood, C. (2014). A century of municipal reform in the United States: A legacy of success, adaptation, and the impulse to improve. American Review of Public Administration, 44, 11S-28S. doi:10.1177/0275074014526299

Wisconsin Legislative Reference Bureau. (2009). 2009-2010: State of Wisconsin blue book. Madison, WI: Department of Administration.

Wisconsin Taxpayers Alliance. (2005). City administrative options. The Wisconsin Taxpayer, 73(3), 1-11.

Wisconsin Taxpayers Alliance. (2012). MunicipalFacts book (Vol. 2012). Madison, WI: Wisconsin Taxpayers Alliance. 


\section{Author Biographies}

Karl Nollenberger received his Ph.D. in public administration from the University of IllinoisChicago. He is an associate professor in the Department of Public Administration at the University of Wisconsin-Oshkosh, where he has been on faculty 2008. His research interests include local government, reform in government, forms of government, decision-making processes in local government, budget priorities, and online versus on campus courses.

James Simmons received his Ph.D. in political science from Indiana University. He is a professor in the Department of Political Science at the University of Wisconsin-Oshkosh, where he has been on faculty since 1989. His research interests include public policy and public administration. 


\section{Appendix}

Survey Questions of As Indicators of Conflict and Cooperation: Mayors

Survey Administered in 2011

Response Rate: $45.2 \%$

Cooperation: Positive interaction or active contributions that match preferences. Low cooperation is the absence of positive interaction or the presence of contributions that fail to meet expectations.

\section{Mayor-Council Form}

Listed below are activities that are usually performed by the mayor in mayor-council cities. For each, indicate how you would rate your performance-is your performance very good, good, satisfactory, poor, or very poor? Check the appropriate box.

\begin{tabular}{|ll|c|c|c|c|c|}
\hline \multicolumn{1}{|c|}{ Rate the mayor's performance: } & $\begin{array}{c}\text { Very } \\
\text { Good }\end{array}$ & Good & Fair & Poor & $\begin{array}{c}\text { Very } \\
\text { Poor }\end{array}$ \\
\hline a. & $\begin{array}{l}\text { Providing the council with sufficient alternatives for making } \\
\text { policy decisions }\end{array}$ & 1.0 & .75 & .50 & .25 & 0 \\
\hline b. & Accomplishing the goals established by the council & 1.0 & .75 & .50 & .25 & 0 \\
\hline $\begin{array}{l}\text { c. } \\
\text { Insuring that city government is open to the participation of } \\
\text { all groups in the community }\end{array}$ & 1.0 & .75 & .50 & .25 & 0 \\
\hline d. & $\begin{array}{l}\text { Providing the council with sufficient information and } \\
\text { performance measures to assess the effectiveness of } \\
\text { programs and services }\end{array}$ & 1.0 & .75 & .50 & .25 & 0 \\
\hline f. & Seeking to improve the efficiency of city government & 1.0 & .75 & .50 & .25 & 0 \\
\hline g. & $\begin{array}{l}\text { Interacting with other local governments and the federal and } \\
\text { state government }\end{array}$ & 1.0 & .75 & .50 & .25 & 0 \\
\hline h. & Promoting economic development of the city & 1.0 & .75 & .50 & .25 & 0 \\
\hline
\end{tabular}

\section{Council-Manager-Form}

Listed below are activities that are usually performed by the mayor in council-manager cities. For each, indicate how you would rate your performance-is your performance very good, good, satisfactory, poor, or very poor? Check the appropriate box.

\begin{tabular}{|ll|c|c|c|c|c|}
\hline \multicolumn{1}{|c|}{ Rate the mayor's performance: } & $\begin{array}{c}\text { Very } \\
\text { Good }\end{array}$ & Good & Fair & Poor & $\begin{array}{c}\text { Very } \\
\text { Poor }\end{array}$ \\
\hline a. & $\begin{array}{l}\text { Serving as a spokesperson for city government and } \\
\text { representing the city in dealings with the public }\end{array}$ & 1.0 & .75 & .50 & .25 & 0 \\
\hline b. & Promoting communication within the council & 1.0 & .75 & .50 & .25 & 0 \\
\hline c. & $\begin{array}{l}\text { Promoting a positive relationship between the council and } \\
\text { the manager }\end{array}$ & 1.0 & .75 & .50 & .25 & 0 \\
\hline d. & Helping the council set goals and priorities & 1.0 & .75 & .50 & .25 & 0 \\
\hline e. & Helping the council adopt policies & 1.0 & .75 & .50 & .25 & 0 \\
\hline f. & Seeking to improve the efficiency of city government & 1.0 & .75 & .50 & .25 & 0 \\
\hline g. & $\begin{array}{l}\text { Interacting with other local governments and the federal and } \\
\text { state government }\end{array}$ & 1.0 & .75 & .50 & .25 & 0 \\
\hline h. & Promoting economic development of the city & 1.0 & .75 & .50 & .25 & 0 \\
\hline
\end{tabular}


Conflict: Negative interactions, including blocking behaviors and activities that disregard others' preferences. Low conflict is the absence of negative interactions and the presence of a low level of activity.

7. In your judgment, what percent of the council decisions that you consider important are made unanimously or nearly unanimously?
Over $75 \%$
$25-49 \%$
$50-74 \% \quad-.33$

\begin{tabular}{|c|c|}
\hline$\underline{O}$ & $50-74 \%$ \\
\hline .67 & Fewer than $25 \%$ \\
\hline
\end{tabular}

8. In general, would you say that there are blocks or factions on the council that consistently vote in the same way on a number of issues? Put an $\mathrm{X}$ by your response.

No, there are no real divisions within the council. $\quad 0$

Yes, there are some divisions but they are not very strong.. .50

Yes, there are sharp divisions within the council. 